\title{
Prophetic Reading: Sisterhood and Psychoanalysis in H.D.'s HERmione
}

\begin{abstract}
This article offers a comparative reading of H.D.'s 1927 kunstlerroman à clef, HERmione, and Freud's Dora alongside an intertextual close reading of its dense web of literary allusions in order to argue that it offers a sustained critique of Freudian psychoanalysis and an alternative origin story for the condition of hysteria. Drawing on the notion of prophecy as it is thematised in the novel, the article demonstrates H.D.'s prefiguring of Juliet Mitchell's recent reconfiguration of hysteria as a response to, replacement by, or failure of identification with a sibling.
\end{abstract}

\section{Key Words}

Hysteria

Psychoanalysis

Siblings

Classicism

Philomel 


\section{Prophetic Reading: Sisterhood and Psychoanalysis in H.D.'s HERmione}

But Her Gart was then no prophet. She could not predict later common usage of uncommon syllogisms; 'failure complex,' 'compensation reflex,' and that conniving phrase 'arrested development' had opened no door to her. ... Words that had not (in Philadelphia) been invented, beat about them: Oedipus complex, inferiority complex, claustrophobia [but] ... Hermione had not been able to predict 'narcissism,' nor cerebral-erotic affinities. ... In those days those astounding Freudian and postFreudian volumes had not found their way into the common library. Hermione Gart would have been astounded in those days to learn that 'Oedipus' links up with the most modern prophets.

H.D., HERmione.

It has been a lively time, and I have a new patient, a girl of eighteen; the case has opened smoothly to my collection of picklocks.

Sigmund Freud to Wilhelm Fliess, October 14, 1900.

The young woman regarding whom Freud wrote to Fliess so jubilantly on that October day was, of course, Ida Bauer, whose story was subsequently published in 1905 as Fragment of An Analysis of a Case of Hysteria, or, Dora. In that same year, or very soon after it, a similarly lively young woman named Hilda Doolittle would suffer a hysterical breakdown following a series of academic and personal disappointments. Twenty years later, H.D. would describe her experiences of this 'peculiarly blighted time' in an autobiographical roman á clef entitled HERmione. This article offers a comparative reading of HERmione and Dora alongside an intertextual close reading of the novel's dense web of literary allusions in order read the two dominant critical discourses of H.D. scholarship — her Classicism and her Freudianism — against one another. In reading H.D.'s allusions as an intertextual network of simultaneously related but competing discourses, my methodology owes something to Wai Chee Dimock's new modernist call to consider the uses made by American writers of longstanding world literary traditions. However, I do so less to stake a claim for H.D.'s 'planetarity' or to draw attention to this text's embeddedness in 'deep time' than, conversely, to reorient our critical temporality to one of futurity (Dimock 2008, 3; 6). That is, to suggest that the motif of prophecy as it appears in the opening lines of the novel is offered to us as a mode of reading - one that demonstrates the extent to which H.D., despite (or perhaps 
because of) her lengthy engagement with Freud as both mentor and intellectual adversary, offered in this novel both a sustained, feminist, critique of his theories and an alternative origin story for the condition of hysteria, which anticipates feminist critiques of the late twentieth century. ${ }^{1}$

Thus, although what is offered here is a close reading of a single novel in H.D.'s considerable oeuvre, what is at stake is a challenge to the dominance of Oedipus in structuring the ways in Freud's theories of kinship and sexuality that I see as part of the ongoing project of reorienting both psychoanalytic literary theory, and, more broadly, the 'Freudian mythologies' (to use Rachel Bowlby's term) by which people in the West have imagined their pasts and their potential futures. As Bowlby notes, even Freud himself recognized the potential mutability of ostensibly rigid categories of identity for both individuals and societies, offering 'varying hypotheses on questions of changing stories or mythologies' across his oeuvre (2007: 7). Where recent theorists have looked to Antigone as an alternative point of departure for thinking through the demands of kinship on individuals, ${ }^{2}$ H.D. similarly imagines a relationship that displaces the parental and heterosexual. In HERmione, she calls upon an imagined 'twin-self sister' to keep at bay the demands made upon her by maternal figures who appear by turns as competitors and consumers as well as avatars of conformity to heterosexual marital relations. Reading HERmione in comparison with Dora reveals the novel's patterns of self-loss and self-gathering — patterns catalyzed by the figure of the sibling - as a carefully plotted, self-consciously ambivalent account of an alternative family romance.

\section{The 'Twin-Self': HERmione and Dora as 'Sister' Texts}

HERmione opens with the lament that Freud's collection of picklocks - terms such as 'failure complex,' 'compensation reflex,' and 'that conniving phrase, arrested development' - had not yet 'opened any doors' for its protagonist (3). This lament suggests, however, that those of us who come after Hermione, and have access to Freud's account of the symptoms and treatment of a variety of neuroses and psychoses, do have the kind of privileged access to her psychic state that she was denied. Moreover, the moments in which the narrator refers to 
Freud, Oedipus and other tools of the psychoanalytic trade have a formal significance, a certain authority, in that they mark what amount to relatively few moments of apparently omniscient intervention into the free indirect discourse and stream of consciousness of the text. Freudian terminology is thus presented to us as a key by which to open the door to H.D.'s text, to link up 'this volume' with others by way of Oedipus; that is, by the associations, displacements and condensations of psychoanalysis.

Yet even as these moments seem to set up Freudian discourse as the explanatory tool that will bring these blighted years into clarity, the novel evinces a complicated engagement with it. Oedipus does not appear in this text solely as an avatar of Freudian analysis, nor is he the only Classical figure on whom H.D. will draw; Narcissus, Calypso, Medusa, Philomel, Persephone and Demeter, to name just a few, are thrown together in the novel in a way that serves not only to link the lexicon of psychoanalysis back to its origins in Classical mythology, but more importantly, reminds readers that the fall of the house of Oedipus is not the only family saga to have come out of Greece. Nor is it even the foremost. In particular, repeated allusions to Procne and Philomel foreground the theme of sorority in this novel over and above the vertical/parental scheme of the Oedipal model. Sorority appears in this novel as a mode of identification that is an alternative to Freud's limitation of identification to either the father or the mother. Far from evincing the matrilineal mythopoesis so central to the work H.D. produced after her analysis by Freud, HERmione offers through its citation of Philomel a version of feminine subjectivity in which the relation between sisters is called upon to annihilate maternity. The myriad references to mythological and Shakespearean characters in this novel are therefore something more than literary allusion. Rather, they coalesce into an intertextual network that amounts to an alternative psychoanalytic origin story for hysteria. Freud's account of hysteria, narcissism and 'inhibited development' (read: bisexuality) thus does not so much appear as an interpretive model in this text, than as itself a sister text with which to identify, but which will, like all identificatory models in this novel, ultimately be found wanting.

I am not, of course, the first reader of HERmione to consider it in relation to Freudian or to Classical Greek intertexts. However, the vast majority of such scholarship focuses on 
sexuality and the origins of sexual difference on the one hand, and Classicism as a literary form on the other. ${ }^{3}$ My intertextual reading seeks to make clear the competing, and often violent demands of kinship on individuals; in particular, the disruptions of maternity by sorority, and vice versa. Nor am I the first to read HERmione alongside Dora in particular. Lidia Yukman has drawn upon Freud's account of hysteria explicitly in order to posit bisexuality as a founding moment for subjectivity rather than a dangerous and destructive uncertainty. In arguing that the narrative of Dora, too, reveals an alternate version of subjectivity as 'process' Yukman $(1996,125)$ rises to her own challenge to 'read Freud back through H.D.'. Yet she concludes her analysis with a question: 'how might H.D. read [Dora]?' (138). Like Yukman, I seek to re-read Dora via HERmione (and read HERmione via re-readings of Dora) but in a way that signals H.D.'s conceptual and temporal distance from Freud, rather than the kind of oscillating fixation on his work that Yukman describes. In contrast to both Yukman's emphasis on H.D.'s resistance to categories of sexual difference and to earlier commentators' readings of sister-love solely as a metaphor for female homosexuality (Freeman and du Plessis 1990, 212; Shugar 1990, 87ff.), I argue that the sister-love which will come to represent same-sex desire in this novel originates in an actual sibling relationship.

Preceded in her father's affections by her brother, Bertrand, and supplanted in her brother's by her sister-in-law, the unsympatico Minnie, the protagonist of H.D.'s experimental novel, Hermione Gart, searches frantically for the 'twin-self sister' whose presence will arrest her rapid psychic disintegration and make her somehow whole again (16). This intense quest for sister-love has commonly, and to a very great extent correctly, been read as a search for the sister-lover. However, in positing Dora as the missing, mutually informative, 'sister-text' to H.D.'s work, I argue that these two texts of hysteria and bisexuality are linked in a third way in that they are both narratives of a younger child's failure at identification with her older sibling. In doing so, I read HERmione as a narrative of hysteria that exists in a relation to the mother's body governed not by the paternal function but by a displacing sibling. The figuration of Her Gart's search for her lost (or has she always been absent?) sister reveals a deep-seated ambivalence about the lateral displacement enacted 
by siblings within the nuclear family. As Dora's hysterical symptoms can be first traced to her competitive relationship with her older brother, so Her Gart's dementia is set in motion by a series of failed identifications with siblings and peers, beginning with her brother Bertrand, exacerbated by his marriage to Minnie, and culminating in the failure of her relationship with her 'twin-self sister,' her mirror-image, the enigmatic Fayne Rabb. Hermione Gart's voice was then prophetic in that her dilemma, as dramatized in the novel, anticipates later critical interventions into Freud's theories of subject formation. H.D.'s rendering of the hysterical subject in relation to the mirror, the womb, and the sibling uncannily prefigures critiques of Freudian psychoanalysis not only by Jacques Lacan and Julia Kristeva, but more recently by Juliet Mitchell.

\section{Sometimes a Sister is (Just) a Sister: Rivalry and Displacement}

As sister texts, Dora and HERmione share several key plot points; as sister figures, Dora and Hermione share several key hysterical symptoms. The cough that Hermione develops following her violent rejection of George Lowndes' no less violent attentions is the most notable: 'Walls were coming close to suffocate, to crush her. ... She said, 'Em, Hem, Um' clearing her throat, making a little choking noise in her throat' $(173 ; 175)$. This 'spasmodic cough' or 'throat symptom' immediately evokes Freud's famous formulation of sensation displacement from the lower body to the upper: the pressure of Herr K.'s erection against Dora's body, he claimed, was displaced upwards to be felt as a restriction of her thorax, hence the tightening of the throat and nervous cough (Freud 1997, 40-41). Hermione's revulsion, claustrophobia and subsequent tracheal discomfort here mirrors almost exactly Dora's response to Herr K.'s attentions: 'Dora had at that moment a violent feeling of disgust, tore herself free from the man, and hurried past him...to the street door' (21).

Hermione's horror and disgust at Lowndes' attentions and the revelation of Fayne Rabb as her love object is indicative of the 'gynaecophilic currents of feeling' that, according to Freud, are 'typical of the unconscious erotic life of hysterical girls' (Freud 1997, 55). Freud presumably would have regarded Hermione's as an open and shut case: due to an unresolved Oedipal complex Hermione has failed to transfer her object choice from her 
mother to her father resulting in neurosis and consequent female homosexuality. The 'perversion' of homosexuality, Freud tells us, is not something that one adopts, but rather, results from the failure to develop from the 'undifferentiated sexual pre-dispositions' of childhood. The pervert, then, exhibits a particular stage of 'inhibited development' (43, original italics).

And so we are returned to 'that conniving phrase' that appears in the novel's opening pages: 'arrested development.' To connive means, etymologically, to close one's eyes to, to wink at, to accept tacitly. To what do we blind ourselves if we accept Freud's phrase uncritically? Another way of asking this might be: in relying solely on the story of Oedipus as the template for all our theories of psychosexual development, to what alternative models are we, as Oedipus himself was, wilfully blinded? To explore this question, I turn to the opening pages of the novel, which stage a kind of agon between the paternal function and the maternal body. In these pages Hermione's sensation of dissolution and drowning is connected to her inability to catch and contain her own image:

She was drowned now, she could no longer struggle. Clutching out toward some definition of herself, she found that 'I am Her Gart' didn't let her hold on. Her fingers slipped off; she was no longer anything. Gart, Gart, Gart and the Gart theorem of mathematical biological intention dropped out Hermione. She was not Gart, she was not Hermione, she was not any more Her Gart, what was she? [...] she tried to concentrate on one frayed disc of green pool or mirror that would refract image. She was nothing. She must have an image no matter how fluid or how inchoate. She tried to drag in personal infantile reflection. 'I am too pretty. I am not pretty enough.' (4-5)

This image reads as a pre-Lacanian rendering of the trials of the infant as it passes through the mirror-stage. For Lacan, before the mirror stage (within the imaginary) an infant has no conception of itself as possessing a whole or unified body: here, in Hermione's case, a sense of one's self as 'fluid' or 'inchoate.' The recognition of the unity of the imago, or representation of the self, paves the way for the child's entry into the symbolic whereby a symbol stands in for a thing - that is, language. Language, and more specifically, the assigning of a proper name allows for the newly born 'I' to be sustained over time (Lacan 1998, 169-70; 1994, 53). But Hermione finds that an insistence on the proper name-'I am Hermione Gart' — does not allow her to 'hold on' to an image of herself. Her dementia manifests itself as a slipping away into nonbeing. For Mitchell, tics, contortions and 
hysterical illnesses are all re-enactments of an infantile fear of erasure from the mother's sight, of the failed re-presentation of the body to the loved one. She suggests, therefore, that Freud misread hysteria as an inhibited development. She reads it rather as a performance of regression; that is, not stasis, but a return to the 'inchoate feeling, to a sense of bodily fragmentation' of a pre-mirror stage (Mitchell 2000, 211). What the hysteric lacks, she argues, is a representation of the body contained either by the mirror, as Lacan would have it, or, as Winnicott would have it, the mother functioning as mirror. Such containment is solidified by the conferring of the proper name - if the body can be named it can be represented even in its absence. But, Mitchell writes, 'when the child feels utterly replaced by sibling or peer, it loses the knowledge that it is represented for the mother (or substitute) that though there is another child to whom attention is given, this one too is still, "in mind" (212). Hysteria, in this sense, is less development arrested than development re-wound.

Mitchell's formulation is particularly compelling in Hermione's case in that it is 'the Gart theorem of mathematical biological intention' that 'drops out Hermione.' This theorem, we learn, was devised by her half-brother Bertrand, a 'celestial mathematician' who is heir and aide to their father, Carl, also an astronomer. Hermione, however, had found the theorem 'tenable' only until she had come to study conic sections. At which she failed. 'Science, as Carl Gart, as Bertrand Gart defined it, had eluded her perception. [...] Science, as Bertrand Gart knew it, failed her... and she was good for nothing' (6). Conic sections elude her perception and precipitate her 'dropping out' of college at Bryn Mawr. Hermione experiences the effect of her failure as strangely literal. Science causes her to become similarly imperceptible, to 'drop out' of sight. In this sense science, like Hermione, is literally good for nothing-ness. What is particularly significant about such invisibility is the application of the theorem for which Bertrand Gart became famous. Bertrand is based on Eric Doolittle, Hilda's older half-brother, who was recognized for his work on binary stars (Doolittle 1918, 137139). Binary stars are divided into two subsets, visual binaries and optical binaries. Visual binaries are known as 'true' binary systems in that they are bound together gravitationally. That is, such stars orbit each other. Occasionally, these visual binary systems will appear as 'eclipsing binaries.' In such systems the passage of one star in front of the other causes them 
to be seen as one individual point of light. In contrast, optical binaries are optical illusions. They consist of two stars which seem close together when viewed in the sky but in fact are separated by vast distances in space. Unlike true binaries, they are not gravitationally bound to each other. The difference between the two can only be determined by prolonged observation of each star's orbit. However, the calculation of orbits requires proficiency in conic sections, the subcategory of celestial mechanics that describes the curves obtained by the intersection of a cone by a plane - the parabola, ellipse, or hyperbola. Hermione's failure in precisely this course of study therefore suggests both a failure at identification with her brother Bertrand, the mathematical prodigy, but also implies a failure of individuation. Hermione is unable to calculate her own trajectory and thus becomes locked into orbit with each new 'twin-self' she discovers.

Such failed identification we see similarly in Dora whose brother, Otto, Mitchell posits as the mirror in which Dora first experienced her unitary self. Mitchell argues that this identification was sustained until Dora tried to usurp Otto's sexual position at puberty, but was denied the satisfaction of having her masturbation recognized. That is, she was denied the capacity for active sexual pleasure that was open to her brother (Mitchell 2000, 107). It is at this point that she first develops hysterical asthma and the infamous throat symptom, not, in fact, after her traumatic experience of Herr K.'s erection. Dora's 'hysteria emanates in childhood from the moment of the breakdown of her identification with her brother' (105, original italics). In Hermione's case, as children she and her brother had been locked into a kind of narcissistic identification:

She did not know why and how she loved her brother. He did not know how and why he loved Hermione. They stared at each other like two hawk-moths, like two hummingbird beetles [...]. Hermione had not been able to predict 'cerebralism,' 'narcissism,' nor cerebral-erotic affinities. (17, my ellipses)

While Narcissism is readily glossed by dipping into one of those 'Freudian volumes,' 'cerebral-erotic affinities' appears to be Hermione's own term for the kind of marriage of true minds she enjoys with Bertrand. As Eric did for the young Hilda, Bertrand stocks Hermione's bookshelves, buying her novels by Carroll, Austen, the Brontës, and Dickens. Their narcissistic addiction to one another-' grey eyes stared at grey eyes with some unexpressed 
and undefined craving, the craving of the fiend almost for his narcotic' — is both enabled and sublimated by their shared literary interests (18). The giving and receiving of books forges an intellectual, 'cerebral-erotic' connection between them that stands in for erotic action.

But when Bertrand 'later turn[s] to mathematics,' Hermione finds she cannot follow and their affinity is shattered. As Dora's hysteria originates from the moment she finds she cannot mimic her brother's masturbation, the radical destabilization of Her's sense of self and station is precipitated by not simply by the shame generated by her academic failure, ${ }^{4}$ but much more specifically by her 'failure to reach Bertrand.'

Someone should have told Her that Bertrand Gart's anodyne would be alien to her. Bertrand Gart's incredible gift for mathematics was his anaesthesia. Hermione reached out, but Celestial Mechanics proved a barrier. She had failed, even the beginning, Conic Sections. She had failed to reach Bertrand. (18)

The severance of their connection by her failure removes the source of identification which has kept her from dissolving into the fluid, inchoate state of the pre-mirror stage infant. Where Dora turns, in Freud's narrative, to desires both Oedipal and pre-Oedipal—for her father, for Herr K, the desire to be a little mother to the latter's children, and at the most secret level, for Frau K as a stand-in for her mother-Hermione seeks an alternative sibling to provide herself with a reflection and thus contain her haemorrhaging sense of psychic unity. In this foregrounding of the sibling relation and its catalysing effect on Hermione's hysterical regression, H.D.'s alternative account of hysteria begins to take shape.

Utterly unsatisfactory to playing the role of containing sibling is Bertrand's wife Minnie, who, to Hermione's intense mortification is referred to as her 'sister.' Worse, Minnie refers to Hermione's parents as 'Mother' and 'Father,' dislodging Hermione even further from her position within the nuclear family:

[...T]o hear Minnie say 'father' was a two-edged theft. It stole from her a presence that left her (no one else had) alone and that again stole from her a presence: ...that half of herself that was forever missing. If her father was also the father to...this thing, then the half of her, that twin-self sister would be forever blighted.' (16)

This 'two-edged theft' we might understand as the double displacement Minnie has enacted - she has replaced Hermione as her brother's love object but has also displaced Hermione's position as daughter. Yet what bothers Hermione most is the violence that 
Minnie, with her 'ringed washed-out blue eyes' and her 'soiled white shoes,' does to the fantasy image Hermione holds of what a sister should be: 'A sister was a creature of ebony strung with wild poppies or an image of ivory whose lithe hips made parallel and gave reflection of like parallel in a fountain basin' (10). The thought of Minnie, however, produces a much less pleasing reflection: 'Forehead too high, hair too lank, eyes that stared and stared, blobs of inconsequent blackness' (11).

It is not simply that Minnie is poorly dressed and unattractive. Minnie, we learn, is unbeautiful because she is 'common.' 'It was an incredible thing,' Hermione muses, but Minnie makes her

feel eight, nine with a page of those fractions which all have to be resolved to something different because one of them is a different common... something. Denominator. ... Minnie... was the one fraction that reduced them all, as family, to that level.' (17, my ellipses)

Unlike the Garts and their associates in New England whose lineage reaches back to old Europe - right down to their insistence on such 'anomalies' as tea cups and tea handles and tea cosies (47)-Minnie is Midwestern. Representative of a national character that is 'nonchalant and aggressive,' Minnie has no place in Hermione's Anglophilic milieu, though the Garts have difficulty in putting their finger on exactly what it is about her that keeps her an outsider in their family. 'She was different. They did not know what it was and they had no words to say it' (46). 'Bertrand's wife had an unhappy childhood,' Eugenia murmurs apologetically in relation to anything Minnie does that might be construed as déclassé (46). Looking into the future, however, Hermione casts her (somewhat enviously) as an avatar of that generation to come who 'put all their energy into 'life' and have no crying need for definition' (47). ${ }^{5}$

In the present of the novel, Hermione will lose no opportunity to belittle, literally, her 'mini' sister-in-law. Small-minded and inconsequential, Minnie is an 'inferior little being' (20). Looking back, Hermione considers herself gracious for having been kind to 'the little woman that Bertrand had one day brought out to see them [who] was so obviously unimportant' (19). Her mistake, however, is assuming that Bertrand will see Minnie with the same eyes. In falling in love with Minnie Hurloe, Bertrand transfers his gaze to a new object. 
The grey eyes that had stared into grey eyes now 'glower in a strange way' (19, my emphasis). No longer mirroring Hermione's, Bertrand's gaze has shifted to the unfamiliar, to an object outside of the family: the unworthy Minnie. Forced to look at the lock of Minnie's hair which signifies her betrothal to Bertrand, Hermione imagines the 'red-brown strand' as 'all the writhing horrors of the famed Medusa' (19). The horror of having to look upon the poor white (and poorly whitened) Minnie Hurloe as a sister turns Hermione to stone, an attitude she will affect until the advent of Fayne Paulina Rabb enacts her return to life.

The enigmatic Fayne Rabb is introduced to Hermione by one of her Bryn Mawr associates, 'the pseudoliterary little snob,' Nellie Thorpe (33). While the latter description may suggest that Nellie is a more accurate reflection of Hermione than is Fayne, it is this girl who is 'fey with the same sort of wildness' (a creature strung with poppies who will run and leap across those Lacedaemonian foothills?) that captures and holds Hermione's gaze. Examples of their specular relationship abound, but can be encapsulated in two key scenes of their meeting. In the first, Fayne is seated opposite Hermione, across the afternoon tea table. A ‘convex Victorian mirror' above Fayne's head 'showed Nellie and Hermione tilted sideways' (51). On first seeing Fayne Rabb, Hermione literally sees also her own reflection.

Across the table with its back to the little slightly convex mirror, facing Her Gart and Jessie was this thing that made the floor sink beneath her feet and the wall rise to infinity above her head. [...] Answer the voice that speaks to you. Don't look at the eyes that look at you. 'A girl I want you to see.' The girl was seeing Her. (52)

The Jessie and Nellie of this quotation are sisters, reflecting one another. It stands to some kind of reason then, that Fayne should be recognized by Hermione as her sought-after sister. Fayne even has eyes like Bertrand's (58). Hermione's bifurcated sense of her own face as 'two convex mirrors placed back to back' — as a mirror lacking a reflection — is resolved into a single image by the advent of Fayne. The back to back mirrors become the twin mirrors of Fayne Rabb's gaze which reduce Hermione's image to one whole and unitary representation. Fayne is the occasion for Hermione to pass through the mirror stage, to gather her fragmented, pre-symbolic self into a perceived whole. Fayne makes Her into both object and subject by looking at her, makes her a something that exists and can be represented. The 
'nebulous,' 'fluid,' 'inchoate' self of the novel's opening pages can finally catch the 'smooth surface' that eludes her grasp and her gaze in the opening pages of the novel $(3 ; 5)$.

Fayne's position as 'a sort of mirror television' (76), which gathers and unifies all of Hermione's 'thousand pieces' (130), is nearly sabotaged utterly by her revelation of the same commonness that made Minnie so impossible a choice of sister. It is suggested by the gossipy Nellie Thorpe that Fayne's mother (she of the several suitors) may not be entirely respectable. She has remained unmarried and 'goes about too much' with her daughter and daughter's friends. Worse, she may even be 'made-up' (132). Although at first Fayne herself seems to have avoided her mother's common taint, on visiting the two at home Hermione is appalled to hear her 'bickering' with her ill-mannered and ungracious mother. The tone of Fayne's voice elicits a fit of snobbery from Hermione who sneers inwardly at the Rabbs' 'filthy little gimcracks, that Wedgwood that's cracked and those chairs. I suppose they're Chippendale. I don't know what Chippendale is but it's the sort of thing people who act like Mrs Rabb have' (154). Observing a prominently displayed photograph of an overdressed and elaborately coiffed Fayne she realizes that Fayne has been made in her mother's image and could not possibly perform the work of reflection Hermione requires. As if to literalize Fayne's likeness to her mother a sudden beam of light hits the surface of the photograph, and, 'shining like a mirror' it reflects Mrs Rabb's face superimposed over her daughter's (159). Hermione is vanquished at this point not only by the vicissitudes of class distinction and her own snobbish impulses but because the merging of Fayne's face with her mother's insists upon Mrs Rabb's prior claim to the direction of her daughter's desire:

The voice of Mrs Rabb strode out fearlessly; it said I know no wrong. I love Paulet. It said I love Paulet in the glittering surface, it rammed I love Pauline at you like the surface (hard and glazed) that hid Paulet in the showy-old fashioned photograph. [...] The voice rasped I am a mother, I am her mother. I am mother, mother, mother.' (159, my ellipses)

In the face of the aggression of Mrs Rabb's maternity, Hermione has no choice but to retreat. How can Fayne be Hermione's twin-self if she is allowed only to have eyes for her mother?

Hermione combats Mrs Rabb's overbearing maternity by constructing her relationship with Fayne in terms of literary precedents where sororal relations are prioritized over both 
maternal duty and marital loyalty. Hermione states on several occasions that 'I am Hermione out of Shakespeare' thus establishing the plot and characters of The Winter's Tale as templates for reading her narrative of thwarted familial and heterosexual identifications. ${ }^{6}$ Hermione is the wife of Leontes, King of Sicilia who is accused by her husband of infidelity with his oldest and closest friend, Polixenes. Sentenced to death as a result, she avoids her punishment through the wiles of the indomitable Paulina who aids her in faking her own death. For sixteen years she dwells in hiding with Paulina before returning to re-claim the throne and child she lost. In describing herself as 'Hermione out of Shakespeare' one might reasonably assume that Her Gart seeks to stage with Fayne Paulina Rabb an alternative account of the long-standing relationship elided by Shakespeare in favour of the famous statue-transformation scene and the reunion of the nuclear family.

In Shakespeare's play it is Paulina's idea to dress Hermione as a statue, a 'dead likeness [which] excels whatever yet you look'd upon/ Or hand of man hath done' (V.iii.1617). And Paulina too will direct her gradual revivification. Fittingly, then, in this reexploration of their relationship, Fayne invites Hermione to a production of Pygmalion in which she plays the eponymous character. ${ }^{7}$ As Paulina/Pygmalion, Fayne Rabb is the occasion for the formerly 'carved, heavy, marble' Hermione to come to life (86). Turned to stone by Minnie Hurloe's Medusa locks, unmoved by George Lowndes' violent ministrations, Hermione is brought alive (and to climax) by Fayne as 'she' and 'Her' and 'her' and 'Fayne' and 'I' and 'me' become interchangeable. 'Her bent forward, face bent toward Her. A face bends towards me and the curtain opens. ...Curtains part as I look into the eyes of Fayne Rabb. 'And I-I'll make you breathe my breathless statue.' 'Statue? You-you are the statue', (163). And later: 'I will not have her hurt. I will not have Her hurt. She is Her. I am Her. Her is Fayne. Fayne is Her. I will not let them hurt HER' (181).

Even more significantly, Hermione imagines Fayne in language that suggests that she sees her lover as her long-sought binary star with whom she is locked into orbit. The 'rings and circles that were the eyes of Fayne Rabb' ripple outwards to engulf the two women in a kind of vortex made up 'of rings on rings of circles' (164). Hermione, if still not necessarily understanding conic sections, thus finds herself directly experiencing the phenomenon that 
caused her to come to grief as a student of Celestial Mathematics. Her circular movement here differs from the 'going round in circles' of the novel's opening lines. The dominant metaphor is still that of falling through water, but instead of drowning and impotently grasping at smooth surfaces, she sees herself reflected in the concentric circles of Fayne's eyes. As their eyes connect, she feels her concentration 'harden' in a way that contrasts directly with the failure of concentration with which the novel opens (161). Fixed into what can only be described as an orbit of 'concentric intimacy' with Fayne, Hermione resolves to follow her lover 'into the space beyond space' $(164 ; 161)$.

\section{'Down and down and further there are other kinships':}

\section{Sorority contra Maternity.}

Hermione claims Fayne as the sister she so desperately seeks, a sister who will keep her from drowning and restore her fractured vision of herself to unity. The things that Hermione senses 'piecemeal,' Fayne sees 'clearly' (178). Hermione figures this relationship as that between Procne and Philomel the two sisters whose intense commitment to an ethics of sorority leads to the death of Procne's son Itylus at his mother's hand. Raped by her sister's husband, who cuts out her tongue to prevent her from reporting his crime, Philomel weaves a tapestry depicting the scene which is then delivered to her sister, Procne. In an act of revenge for Philomel's defilement, Procne kills her own son, Itylus and serves him as a meal to his father, Tereus. As a result of their crime two women are transformed into birds, Procne, the mourning swallow, and Philomel, voiceless in human life, becomes the nightingale. This myth is one of many which situate sorority as anterior to maternity and therefore enjoying a higher, since prior, claim and clearly testifies to a profound anxiety in the Classical world about the conflicting ethical demands on a woman of her birth and marital families. ${ }^{8}$ Procne shockingly and categorically repudiates her commitment to heterosexual family lifedestroying her husband through their son - so as to avenge the violence enacted on the body of her sister. Similarly, Hermione renounces her engagement to George in order to honour her devotion to Fayne: 'I won't. I promise you I won't ever marry George, my swallow' (179). Where Freud located lesbian desire in pre-Oedipal attraction to the mother, H.D.'s 
revisioning of love between women is rooted in the rejection of the mother and her stifling heterosexual desire.

H.D. introduces the model of sister-love as a figuration of same-sex desire through her evocation of Swinburne; specifically, her judicious selection and incorporation of quotations from 'Faustine,' Atalanta in Calydon, and, most significantly, 'Itylus.'

Swinburne's well-known forays into the depiction of forbidden love allowed H.D. to embed a lesbian relationship in her text through careful use of allusion and citation. Quotations from Atalanta in Calydon are decontextualized such that Hermione becomes the hunted, the victim of George's sexual predation rather than the famed virgin huntress, while her blissful repetition of 'your face - your face - your face - your face-your face Faustine' is robbed of some of its ecstasy for readers by the knowledge that Faustine describes the faithlessness and ruthlessness of a bisexual seductress (164). What seems to be an enunciation of Hermione's direct encounter with the face of the other is an intimation of the other's bad faith. The stories Swinburne's poems tell, then, seem clear enough. Forbidden desire leads to violent loss and endless mourning. Why then, does H.D. represent love between women in this way? Indeed, Hermione suggests it is the only way: 'There was only one thing to read to Fayne; she had read and she would re-read it. [...] O sister my sister $O$ singing swallow, the world's division divideth us' (179, original italics). We might gloss these lines as: the world's insistence on adherence to the heterosexual norm divides and conquers the love of two women for one another. Yet both Hermione and Fayne are figured at different times not simply as the swallow and the nightingale, but also as Itylus, the murdered child. The poem is, in fact, a reproach to Procne, the swallow, on behalf of her murdered son whose blood cries out, 'Who hath remembered me? Who hath forgotten?' Where Dana Shugar (1990, 87ff) argues that H.D. displaces Procne and Philomel's violence onto the 'Tereusian' world of rape and annihilation, I see Hermione's conflation of herself/Fayne/Itylus as an exhibition of her desire to find asylum from maternal aggression as much as male violence.

The sister who was to protect Hermione from drowning in the mother's desire, or being annihilated by the mother's disappointment, by catching and holding Hermione's image in her gaze has revealed herself to be complicit in the psychic violence enacted against 
her. The fragile identification Hermione builds with Fayne is destroyed by the realization that Fayne has betrayed her by taking up with George Lowndes. The temporary loss of self of orgasm at which point Hermione is transformed in some way into Fayne ('She is Her. I am Her. Her is Fayne. Fayne is Her') becomes dangerously close to permanence. ${ }^{9}$ Presumably expecting to be brought back to herself by the vision of her own image reflected in Fayne Rabb's eyes, she is confronted instead with the knowledge that she has been displaced in this coveted position by George Lowndes. Their blissful spinning in 'concentric intimacy' comes abruptly to a halt, leaving Hermione confronted by the 'blank pool surface' next to which we, as readers, first meet her (164). With neither binary star nor reflection to sustain her subjectivity, her nervous cough develops into a sore throat which becomes, in turn, a fever, bringing with it delirium into which she rapidly sinks. Without Fayne's stabilizing presence Hermione is 'whirled...into obliteration,' her verb choice evoking the cone-shaped maelstrom of a whirlpool. Conic sections provide the metaphor for her failure, this time a failure to maintain her own presence in the symbolic order.

The vortex of her delirium whirls her backwards through a psychic wormhole to a time before she was a subject: 'her mind, galvanized almost to the point of extinction, had turned inward, had thrust Her Gart backward' (13). Finding herself in a place which is 'nowhere' (207) she fights to form her thoughts into coherent, linear patterns but is returned again and again to sensations of 'vibration,' 'whirring,' 'seething,' and the sound of laughter (206-209), experiences that imply a return to the pre-symbolic, pre-natal space of the chora. ${ }^{10}$ Describing herself as a white butterfly she considers unfurling her antennae to probe outside her delirium but concludes it is better to remain safely cocooned inside the leaves 'wrapped around the unborn butterfly' (216). But however cosy it is in her cocoon, withdrawal from the symbolic order can only be temporary. All that has been erased must 'be written on presently' (222); words were both Hermione's 'plague' and her 'redemption' (67).

And indeed, emerging from her sickroom, Hermione discovers that a blizzard has made the world 'clear like a blackboard' - a clean slate on which she can begin anew (223). In what is commonly read as a tentative but defiant act of creation she walks across the meadow towards Farrand woods and her footsteps trace out 'wavering hieroglyphs upon 
white parchment' (224). ${ }^{11}$ Yet Hermione looks upon her tracks with disinterest. These are not yet the perfect expressions of the essence of things that will so preoccupy the later H.D., but are unbeautiful, uneven - perhaps because they have been created unwillingly, with one foot 'trailing,' refusing to do the other's bidding (224). The body Hermione experienced as fractured in her dementia has not yet resolved itself into a coherent whole with a coherent purpose. As she rushes down the embankment and into Farrand Forrest she is returned to where the novel began the previous spring: by the pool in the woods which will resolutely not give back the image she seeks. Words and their possibilities for word play, or as she terms it 'word-reaction' come crowding into her mind as she reaches the forest pool, but the snow's expansive whiteness continues to act as an anaesthetic, dulling her reactions to the memories evoked by returning to this place. Her own psyche does a valiant job of playing 'nursemaid' here in order to protect her from the radical disorientation her return to the pool in the woods may provoke as she muses that she could have 'really written but it's better really to give in to people, be quite ordinary and quite happy like all people' $(223 ; 224)$.

But in stepping out upon the frozen pond, the ice she stands on dips and snaps, and the reverberation of the breaking ice travels rapidly up through her body, 'snapping' her out of her careful charade of banality. On and on the vibration of the breaking ice extends, out through 'the winter branches etched above her head,' and beyond them, until 'it touched stars' (225). This reverberation and the jaggedly cracked ice evoke both the 'Brrr-oooooommm' and the 'sizzling white fire' of the lightning that flashed during the storm in which Hermione was born, and the repetition of this scene through Eugenia's recollection of it (89). As Hermione experienced Eugenia's memory of giving birth as a recapitulation of separation from her mother, so she experiences this moment of reverberation as another separation. However, it is not Eugenia, but Fayne who is invoked by the vibrating ice. The 'reverberation of the break' is 'like Fayne, exactly' (225). It is Fayne, her 'twin-self sister' from whom Hermione separates here:

When she said Fayne a white hand took Her. Her was held like a star invisible in daylight that suddenly by some shift adjustment of phosphorescent values comes quite clear. Her saw Her as a star shining white against winter daylight. (225) 
Conic Sections is the subset of Celestial Mechanics which allows for the calculation of the orbits of stars. It is as though in this moment, Hermione is finally able to identify her own path. No longer locked into orbit with a specular double, she sees herself for the first time. Her act of seeing is also an act of reparation, of gathering her fractured and fragmented self into a coherent and self-possessed image.

That her body feels 'cracked, somewhat injured' testifies to the break that has taken place, but she leaves the woods with a new sense of purpose, which, by the time she has returned home will have coalesced into a feeling of being 'at one with herself [and] with the world' $(226 ; 234)$. A brief encounter with Jimmie Farrand and his friend Harold Grim on her way home gives structure to this purpose: she will travel to Europe on a honeymoon of sorts with Jimmie and Grim, and in doing so will lay to rest her sense of having failed at what is expected of her. Her failure to effect a conventional heterosexual marriage is transformed into an opportunity for travel in that the money set aside for her trousseau will be diverted into funding her Grand Tour. Her failure to complete her college degree, to conform to 'rows of desks and stabilization and exact formalization' is similarly converted into a perverse point of pride. 'I flunked the whole lot,' she confesses of her classes at Bryn Mawr, and in admitting it, she feels 'glad and comforted' (231). These thoughts 'sustain' Hermione's newly-found sense of independence and self-possession as she hurtles back to Gart Grange. Secure now in her own familial and social position, she even resolves to reconcile with Minnie and atone for the strain her illness placed on Eugenia. With these thoughts driving her, Hermione 'barge[s] straight into Mandy' who utters the enigmatic sentence with which the novel closes: 'Oh Miss, I thought you was back long since. I done left Miss Fayne all alone in your workroom' (234).

Mandy's syntax implies that Hermione's separation from Fayne is still in place at this textual moment. Hermione, in finally becoming 'at one with herself' has left Fayne 'alone,' which we may read as 'all one,' that is, wholly individuated. Yet the question raised by the novel's abrupt conclusion is whether this separation will hold - a question which has provoked widespread critical contention. There are those who see the presence of Fayne in Hermione's workroom as evidence of a new beginning. For such readers, the 'literary and 
biographical' journey of Fayne/ Frances and Hermione/ Hilda is full of promise, poised to progress to its next stage (Travis 1987, 139). And indeed, as Friedman and DuPlessis (1990, 214) have pointed out, if readers move directly from HERmione to Asphodel (written several years before HERmione, it records the story of Hermione's journey to Europe with Fayne Rabb and her mother) they will encounter Hermione and Fayne in France, having embarked on the next phase of their life together. Yet the story Asphodel tells is of the failure of this relationship, and therefore Mandy's words may be construed as ominous in tone in that the presence of Fayne in Hermione's workroom indicates that her sense of independent purpose will be short-lived (Benstock 1986, 348-349). However, both of these readings require 'prophetic' knowledge on behalf of the reader. The influence of such knowledge is hard to avoid given the heavy-handed 'Postlude' added to the 1981 version of the novel in which the final separation of Frances Gregg and H.D. is effected by an insistent Ezra Pound, but without this postlude, the final pages of the novel do not even attempt to predict the future of this relationship.

The inconclusive conclusion of HERmione suggests that it is not its content, but its form that provides us with the final 'picklock' by which to 'open the door' to an understanding of the novel. The abruptness of this ending, as though the account we have has in fact been broken off from a larger whole, gives the novel the status of a fragment. In this fundamental, structural way, then, the narrative of HERmione once again signposts its resemblance to the story of Dora, which ends similarly abruptly when she terminates her appointments with Freud. Thus, while I agree with Chisholm $(1992,77-81)$ that H.D.'s text follows the structure of a 'case history narrative,' where she advocates reading it vis-à-vis Breuer's case study of Anna O. in Studies on Hysteria, I argue that such a reading fails to account for the novel's fragmentary structure. Chisholm sees the 'stalemate' of its conclusion as evidence of H.D.'s failure to perform an adequate critique of Freud; however, I read this as H.D.'s acknowledgement of the unfinished business (and inadequacy) of Freudian analysis. Just as we hear no more of Dora once she is 'reclaimed by the realities of life' (Freud 1905, 112) we will hear no more from Her Gart at this moment of reconnection 'with herself, with the world, with all outer circumstance' (234). 
Hermione Gart was then no prophet. She does not tell what will come to pass, but simply what has been. But in doing so, she (or rather, H.D.) dramatizes some surprisingly contemporary questions about kinship which have preoccupied theorists seeking both to extend and to critique the Freudian psychoanalysis with which H.D. had just begun to come into contact. HERmione posits identification with the sister as an alternative to identification with the mother, but sisterhood is an identificatory model that brings with it its own set of dissatisfactions. Some sisters - Minnie - will be tested and found wanting due to too radical an alterity, but ultimately, the 'twin-self sister' Fayne, will also fail Hermione because they are too much alike. H.D. gives us in HERmione a narrative of hysteria which does not simply seek to give the hysteric a voice, or to turn what others would deem 'madness' into an innovative form of poetic expression (although it does both), rather, it stages a significant intervention into psychoanalytic theory.

${ }^{1}$ Lidia Yukman notes the "remarkable" clairvoyance of H.D.'s work, arguing that her novels engage with "a deconstructionist model of language, a revised psychoanalytic model that addressed the female and maternal self, and the possibility of the production of a bisexual self.” (1996, n.139). Yet Susan Edmunds expresses scepticism about H.D.'s ability ‘to anticipate...theoretical concepts and political stances that we as critics are even now learning how to articulate'; however, her analysis focuses on H.D.'s poetry and thus does not engage the specific motif of prophecy and its call to readers in HERmione (1994, 4). Moreover, I argue that such anachronistic reading of this novel is prompted not only by its framing trope of prophecy but by the strange temporalities of the novel itself. Written in 1927 and describing events of 1905-07, there is some evidence the novel was being prepared for publication at the time of H.D.'s death in 1961, but was not in fact published until 1981. 2 Judith Butler's Antigone's Claim (2000) is most notable in this regard. Subsequent treatments of Antigone (Butlerian and otherwise) are well represented in Tina Chanter and Sean D. Kirkland's The Returns of Antigone (2014).

${ }^{3}$ Claire Buck's H.D. and Freud: Bisexuality and a Feminine Discourse extends Susan Stanford Friedman and Rachel Blau DuPlessis' germinal analysis of H.D.'s rejection of prescriptive Freudian norms in essays such as 'Woman is Perfect: H.D.'s Debate with Freud' (1981) but questions their emphasis on her quest for a feminine voice, advancing instead the argument that 'the interest of H.D.'s work lies less in the achievement of a new mode of identity or femininity than in her persistent questioning of the terms of subjectivity itself' (1991, 12). See also Susan Stanford Friedman and Rachel Blau DuPlessis, "I had two loves separate": The Sexualities of H.D.'s HER' in Signets: Reading H.D. (1990). Buck foregrounds the significance of translation as both practice and trope in H.D.'s writing, a facet taken up by Dianne Chisholm's thematic study of the entire corpus of H.D.'s work. H.D. 's Freudian Poetics: Psychoanalysis in Translation (1992) identifies her creative modus operandi as a process of 'translation,' interpretation and revision of Freudian psychoanalysis which ultimately calls for a critical re-reading of Freud's theories of feminine sexuality. 
H.D.'s version of 'Hellenism' was decried almost as soon as it came into being. Dismissed by both Eliot and Pound as 'narrow, false and decadent,' her move away from the 'technical virtues' of the new classicism met with a scathing and detailed refutation at the hands of Douglas Bush, leading, in Eileen Gregory's view, to her 'burial' in modernist literary history (1997, 14-15).

${ }^{4}$ See, for example, Sarah Wood Anderson's claim in Readings of Trauma, Madness, and the Body, 39.

${ }^{5}$ For an extended discussion of H.D.'s ambivalent Anglophilia in HERmione and complex sense of her own national identity see Bryony Randall, 'Funny, but no hybrid': H.D., Tea and Expatriate Identity.'

${ }^{6}$ The Winter's Tale is itself a revisioning of the myth of Demeter and Persephone. The 'winter's tale' being the long barren period of separation between mother and daughter, Hermione and Perdita. See W. F. C. Wigston in William Shakespeare, The Winter's Tale (London: Arden, 2000), xlii.

${ }^{7}$ While readers may assume that the play embedded in H.D.'s mass of allusions is Shaw's Pygmalion, its performance at the time in which the novel is set (around 1906) is an anachronism. Shaw's play was not performed until 1916. It may be then that the play in which Fayne performs is a representation of the original Greek myth — in which case it makes sense that Fayne should appear wearing a Greek tunic. Yet given that the Pygmalion of Shaw's play is the linguist Professor Higgins while his Galatea is a certain Miss Doolittle, it seems highly unlikely that Shaw's version is not the one that H.D. had in mind.

${ }^{8}$ Others include the myth of Antigone, who has no son, but insists that the position of brother demands greater loyalty than even that of a mother for her child. Indeed, she sacrifices her chance at the consummation of a heterosexual partnership with Haemon by her illegal burial of her brother. See also the story of Althaea who kills her own son as a consequence of his murder of his uncles, her brothers. Althaea is referenced obliquely in HERmione via the citation of Atalanta, on whose behalf Althaea's son murdered his uncles. Interestingly, the women who mourn the men killed in both sides of this conflict are also turned into birds. ${ }^{9}$ As Mitchell notes, the giving up of the body in orgasm is, for the hysteric, too close to death and annihilation. See Mad Men and Medusas, 211.

${ }^{10}$ For an extensive analysis of the Hermione's mental and physical breakdown in relation to the irruption of semiotic motility into the symbolic order see S. Travis, 'A Crack in the Ice: Subjectivity and the Mirror in H.D.'s HER.'

${ }^{11}$ See, for example, Deborah Kelly Kloepfer, 'Flesh Made Word: Maternal Inscription in H.D.' Sagetrieb: A Journal Devoted to Poets in the Pound-H.D.-Williams Tradition 3.1 (1984), 43; S. Travis, 'A Crack in the Ice,' 135; Friedman and DuPlessis, Signets, 213. 